\title{
United States Department of Agriculture Forest Service 1996 Annual Report Wetlands Research Related to the Pen Branch Restoration Effort on the Savannah River Site
}

by

E. A. Nelson

Westinghouse Savannah River Company

Savannah River Site

Aiken, South Carolina 29808

R. K. Kolka Dr.

USDA Forest Service

SC USA

C. C. Trettin Dr.

USDA Forest Service

SC USA

DOE Contract No. DE-AC09-96SR18500

This paper was prepared in connection with work done under the above contract number with the U.S. Department of Energy. By acceptance of this paper, the publisher and/or recipient acknowledges the U.S. Government's right to retain a nonexclusive, royalty-free license in and to any copyright covering this paper, along with the right to reproduce and to authorize others to reproduce all or part of the copyrighted paper. 


\section{DISCLATMER}

This report was prepared as an account of work sponsored by an agency of the United States Government. Neither the United States Government nor any agency thereof, nor any of their employees, makes any warranty, express or implied, or assumes any legal liability or. -responsibility for the accuracy, completeness, or usefilness of any information, apparatus, product, or process disclosed, or represents that its use would not infringe privately owned rights. Reference herein to any specific commercial product, process, or service by trade name, trademark, manufacturer, or otherwise does not necessarily constitute or imply its endorsement, recommendation, or favoring by the United States Government or any agency thereof.: The views and opinions of authors expressed herein do not necessarily state or reflect those of the United States Govemment or any agency thereof.

This report has been reproduced directly from the best available copy.

Available to DOE and DOE contractors from the Office of Scientific and Technical Information, P.0. Box 62, Oak Ridge, TN 37831; prices available from (615) 576-8401.

Available to the public from the National Technical. Information Service, U.S. Department of Commerce, 5285 Port Royal Road, Springfield, VA 22161. 


\section{DISCLAIMER}

Portions of this document may be illegible electronic image products. Images are produced from the best available original document. 


\title{
UNITED STATES DEPARTMENT OF AGRICULTURE FOREST SERVICE
}

\section{ANNUAL REPORT}

Wetlands Research Related to the Pen Branch Restoration EfFort on the Savannah River Site

\author{
Prepared by: \\ Dr. Randall K. Kolka \\ Dr. Carl C. Trettin
}

Center for Forested Wetlands Research Southern Research Station USDA Forest Service Charleston, South Carolina

January 1997

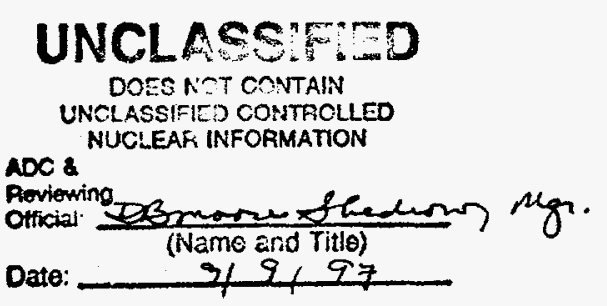


Pen Branch Monitoring;

History

Monitoring

Hydrology

Vegetation

Pen Branch Research

Summary

Stream Communities

Stream Morphology and Stream Community Characteristics 5

Ecological Risk Assessment and Stream Restoration Relative

to Thermal Filow Disturbance

Autotroph and Macroinvertebrate Post-Thermal Recovery and

Restoration of a Coastal Plain Stream

Vertebrate Comnunities

Reptile and Amphibian Characterization of the Pen Branch

Corridor at the Beginning of Restoration

A Comparison of Avian Communities in Bottomland Hardwoods 10 of Different Successional Stages

Pen Branch Small Mammal Program

Vegetation

Comparison of Biomass Partitioning and use of Physiological

Parameters in Determining Long Term Survival of Four

Wetland Trees Species

The Use of Koot Pruning and Tree Shelters in Regenerating

Forested Wetlands in Pen Branch

Optimum Overstory Condition for the Survival and Growth of Late-Successional Seedlings

Soil Nutrients and Carbon Flows

Soil Organic Matter Development and Characterization:

Successional Patterns on a Forested Floodplain

Comparison of Carbon and Nutrient Fluxes among Wetland Systems at Different Successional Stages

Distribution and Function of Organic Matter Pools among

Systems of Different Successional Stages

Wetland Assessment.

Development of a Wetland Evaluation Technique Specific to the Reforested Pen Branch Corridor and Delta 
WSRC-TR-97-00273

\section{List of Tables and Figures}

Table 1. Research conducted concerning the Pen Branch bottomland hardwood system.

Page

iv

Table 2. Results of the 1996 seedling establishment

survey (Gartner, 1996).

Figure 1. Stage height hydrograph of upper Pen Branch, 2 June 1996 - December 1996.

\section{Acknowledgments}

This report represents the collective efforts of the principal scientists and their staff. Without the open exchange of information and collaboration, this project would not be possible. We appreciate their time and efforts in preparing the material for this report. We also appreciate the work of Cary Coppock for his work in preparing this document. This interagency effort could not be possible without the oversight, committment and support of John Blake of the Savannah River Forest Station and Eric Nelson of the Savannah River Technology Center. Their help and leadership is appreciated.

\section{Preface}

This report documents the role of the USDA Forest Service and their collaborators (SRTC, SREL, and several universities) in wetlands monitoring and research on the Savannah River Site. Much of the information concerns the Pen Branch bottomland hardwood wetland and ongoing studies of the restoration effort in that system. Twelve major research projects are either ongoing or have concluded in 1996 (Table 1). Ten of the twelve projects are either being conducted by the USDA Forest Service or are financially supported by the Forest Service. Several studies have joint researchers of funding from several organizations. This report describes the rationales, methods and results (when available) of these studies and summarizes and integrates the available information through 1996. 
Table 1. Research conducted concerning the Pen Branch bottomland hardwood system.

Research Topic Principal Investigators Status

Fish Communities and

Stream Morphology*

Drs. Marcel Reichert and John Dean

ongoing

Fish Communities and

Habitat Structure ${ }^{+}$

Drs. Dean Fletcher and Gary Meffe

ongoing

Autotroph and Macroinvertebrate

Communities $^{+}$

Dr. J Vaun McArthur

ongoing

Herpetofauna Communities*

Drs. Hugh Hanlin and David Guynn

concluding

Avian Communities*

Drs. Karl Miller and Brian Chapman

concluding

Small Mammal Communities"

Dr. Lynn Wike

concluding

Biomass Partitioning in

Seedlings"

Dr. Donal Hook

concluding

Methods for Seedling

Establishment"

Dr. William Conner

concluding

Seedling Survival/Competition Study*

Dr. Martha McKevlin, Neil Dulohery and Dr. Carl Trettin

concluding

Soil Organic Matter Quality**

Dr. Graeme Lockaby

ongoing

Hydrological Fluxes of Carbon and Nutrients*

Drs. Randall Kolka and Carl Trettin

ongoing

Distribution and Function of

Organic Matter Pools*

Dr. Michael Aust

ongoing

Development of a Wetland

Evaluation Technique* Drs. Carl Trettin and Eric Nelson concluding

* Research projects conducted or supported by the USDA Forest Service.

+ Research projects conducted or supported by the Savannah River Ecology Lab.

" Research projects conducted or supported by the Savannah River Technology Center. 
WSRC-TR-97-00273

\title{
Pen Branch Monitoring
}

\author{
History
}

For over thirty years the bottomland hardwood system of the Pen Branch corridor and delta was used for the discharge of coolant water from K reactor at the Savannah River Site. Prior to reactor placement, flow in Pen Branch was typically 10-20 cfs. Reactor operations raised the flow to as much as $400 \mathrm{cfs}$ (Nelson, 1996). Coolant waters were consistently $40-50{ }^{\circ} \mathrm{C}$ and by 1989 , when the reactor was retired, this hightemperature, elevated flow effluent had removed virtually all vegetation and eliminated the seed bank and root stock from the bottomland hardwood wetland. By the early 1990 's, a dense black willow thicket covered the floodplain and delta with very little sign of the predisturbance bottomland hardwood system.

In 1992 the USFS began efforts to accelerate the restoration of the Pen Branch system to its previous bottomland hardwood state. The area was divided into three habitats or sections based on hydrology and vegetation present; upper corridor (61 ac); lower corridor ( $39 \mathrm{ac})$; and delta $(123 \mathrm{ac})$. Approximately $75 \%$ of the entire area was planted with trees using various site preparation techniques (e.g. no site preparation, herbicides, burning). Planting was done in strips with nonplanted control strips between each planted area. Species were selected based on soil type and hydrology in the floodplain corridor and delta. The species planted were cherrybark oak, water oak, Shumard oak, swamp chestnut oak, water hickory, pignut hickory, persimmon, green ash, sycamore, swamp tupelo and bald cypress. Following each planting, surveys were conducted to monitor survival and growth (Dulohery et al., 1995). Areas understocked were replanted in 1995-1996. A detailed description of the history of thermal discharge, the environmental impacts and the reforestation effort can be found in Dulohery et al. (1995).

\section{Monitoring}

Long-term monitoring of the Pen Branch system was designed to meet future management objectives and regulatory considerations when assessing the recovery of the wetland. Monitoring focuses on hydrology and vegetation establishment. For more details of monitoring efforts during restoration activities, see Dulohery et al. (1995).

\section{Hydrology}

A significant monitoring effort was conducted from 1991-1995 to characterize the hydrology of the Pen Branch system as well as Fourmile Creek and Steel Creek - two other thermally impacted streams being considered for restoration (Dulohery et al., 1995). Waters flowing in Pen Branch are augmented with unheated flow from K-reactor pumps. Although K-reactor flows have been periodically reduced since 1991, the reactor discharge still plays a significant role on the hydrology in Pen Branch..

The primary objectives of the hydrologic monitoring were to:

1) determine the influence of pumping on site hydrology,

2) characterize the hydrology of the site as reactor pumping is diminished,

3) aid in determining suitable tree species and management alternatives based upon the expected long term hydrology. 
The results of that monitoring led to the following conclusions concerning the three primary objectives (Dulohery et al., 1995).

1) Pumping of unheated water from $\mathrm{K}$-reactor caused flooding and saturation of soils throughout the Pen Branch corridor as late as the summer of 1992. Such pumping, if resumed, will limit the number of tree species suitable for the corridor.

2) Future long-term monitoring can be achieved adequately with a small number of continuous water-level recorders. The initial monitoring showed strong spatial correlations in water table depths among many of the well locations, and continuous recording will enable better characterization of flood events.

Hydrologic monitoring resumed in June of 1996. A single continuously recording water-level recorder placed in the stream in the upper corridor is currently monitoring hydrology. The results of that monitoring are shown in Figure 1. Low flows in August are caused by the shut down of K-reactor pumps for about a two week period. The shutting down of the pumps allowed us to evaluate the magnitude of augmented flow from pumping. Currently, discharge from K-reactor supplies approximately 20-30\% of the flow or $25 \mathrm{~cm}$ (one foot) of stage height.

Figure 1. Stage height hydrograph of upper Pen Branch, June 1996 - December 1996.

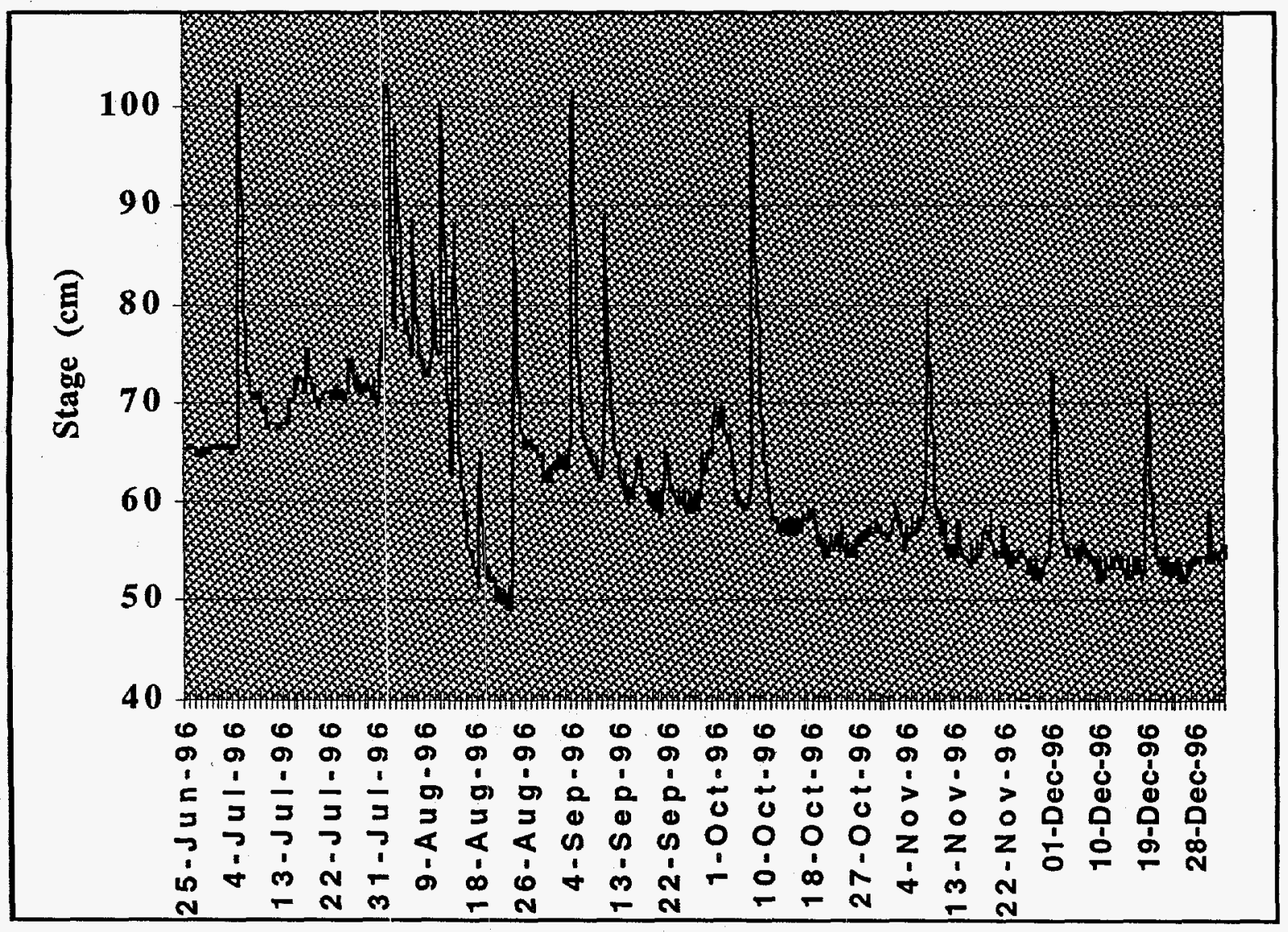




\section{Vegetation}

Following planting, surveys were conducted to monitor survival and growth (Dulohery et al., 1995). In 1996, a systematic survey of seedling establishment was conducted. A detailed description of the 1996 survey and results can be found in Gartner (1996). The objectives of the 1996 survey were two-fold; 1) measure enough plots to determine if any major gaps or holes in survivalship exist in planted areas, and 2) provide statistical information for the design of the more intense survey to be conducted in the spring of 1997.

Results of the 1996 indicated good survivalship of planted seedlings with section means in planted areas over the desired level of 200 trees/ac set by the Forest Service (Table 2). Only one strip ( $H$, see map) in the lower corridor had a mean $(194.4 \pm 94.4$ standard error) with fewer seedlings than the desired level of establishment. Approximately $12 \%$ of the seedlings were volunteers from species that had not been planted. Because undesirable species were not counted (black willow, buttonbush, wax myrtle), it is apparent from the results that at least some areas in the upper corridor controls were mistakenly planted. These areas are being documented for further reference. Currently the results of 1996 survey are being used to effectively design the more intensive 1997 survey.

Table 2. Results of the 1996 seedling establishment survey (Gartner, 1996).

\begin{tabular}{lccr} 
& Mean (\#/ac) & Standard Error & \# Plots \\
\hline Upper Corridor Planted & 290.2 & 64.2 & 51 \\
Upper Corridor Control & 211.5 & 51.6 & 13 \\
& & & \\
Lower Corridor Planted & 225.0 & 44.0 & 24 \\
Lower Corridor Control & 63.3 & 21.5 & 15 \\
Upper Delta Planted & 550.0 & 80.0 & 48 \\
\hline
\end{tabular}

\section{Pen Branch Research}

The following section describes each of the research projects, either ongoing or concluding in 1996. Each of the project summaries were submitted by the investigators. The section begins with a summary and integration of available information through 1996.

\section{Summary}

\section{Objectives}

As shown by the breadth of research being conducted in the Pen Branch, the focus is on the assessment of ecosystem level processes that are occurring as succession proceeds. Comparisons of populations and processes across successional gradients and treatments allows the effect of disturbance and restoration activities to be evaluated.

The main objectives of the Forest Service are to develop best management practices for physically performing restorations and to develop monitoring methodologies to assess restoration effectiveness. All of the studies support these objectives. Knowledge gained from the following studies will enable future restoration efforts to be more efficiently and effectively performed and evaluated. 
WSRC-TR-97-00273

\section{Performing Restorations}

Several of the studies have provided invaluable information on how to best perform reforestation in disturbed bottomland hardwood systems. Seedling establishment appears to be hampered in open conditions because of herbaceous competition and herbivory. The highest probability for seedling survival appears to be in conditions where a shrub cover or nurse crop is present. Although shading effects might slow seedling growth to some extent, the effects are offset by protection from herbaceous competition and deer and feral hog herbivory. Future reforestation efforts in bottomland hardwood wetlands should considler minimal mechanical site preparation techniques as alternatives.

Seedling survival and establishment is much greater when tree tubes are used. Although tree shelters maybe cost prohibited on a large scale project such as the Pen Branch reforestation, they may be cost effective to use them in areas where seedling establishment is deemed critical. If stream stabilization and stream community recovery are primary restoration objectives, assuring seedling survival adjacent to streams with tubes may be a viable alternative. In relatively short period of time, these seedlings will stabilize the banks and provide the light conditions necessary for stream biota recovery.

Root pruning eases planting of species in muck conditions such as those found in the Pen Branch delta. Although very preliminary, it appears that root pruning does not have a detrimental effect on seedling survival, at least for bald cypress, water tupelo, swamp blackgum and green ash. If future results support this finding, planting in these difficult conditions can be more efficiently conducted.

Studies investigating the interaction of seedling survival with hydrologic conditions show that green ash is more susceptible to prolonged flooding than are bald cypress, water tupelo and swamp blackgum. Prolong soil saturation and inundation are typical conditions in the Pen Branch delta and other stream deltas in the area. Future reforestation in deltas or other areas that experience prolonged floods should choose species that are consistent with these findings. We are hopeful that the 1997 seedling establishment survey will also provide some coarse guidelines for species survivalhydrological interactions that can be used to better design future bottomland hardwood restoration activities.

\section{Assessing Restoration Effectiveness}

Most of the studies are in support of assessing restoration effectiveness by comparing treatment areas in Pen Branch with other systems at various levels of disturbance and succession. For restoration to be considered effective, wetland functions need to be restored or at least on a trajectory where restoration of those functions is probable. To develop easily measurable indicators of wetland functions, interactions between abiotic and biotic processes need to be investigated. The abiotic components such as soil and hydrologic conditions, nutrient turnover, light intensity and water chemistry are the driving mechanisms for floral and faunal community establishment.

Currently, the vegetation in the Pen Branch wetland is dominated by early successional herbaceous species in planted areas and a shrub canopy of black willow and an understory of herbaceous species in the control areas. Instream vegetation is dominated by dense mats of macrophytes. Open conditions created by the disturbance and by site preparation led to light regimes that were favorable for these early successional species to become established. The availability of fast decomposing biomass that is currently in the Pen Branch corridor and stream is leading to high rates of instream faunal activity. Although no results are presented concerning autotroph and macroinvertebrate populations, it is clear from fish population densities that insect populations are also higher than in late successional systems. Although not compared to a control system, it is obvious that reptiles and amphibians are well established. Bird species follow the same trend with no differences in abundance between early 
successional systems and late successional systems, although species diversity and richness were greater in the late successional system.

It appears from the data that Pen Branch is performing many of the functional capabilities of a wetland with respect to fauna. For some faunal communities, it appears that Pen Branch is providing greater opportunity for establishment and survival than in late successional control systems. Although species abundance and in some cases diversity are higher in Pen Branch than in control systems, the community structure is very different. Initial results suggest that certain species dominate populations in Pen Branch and the distribution of species is very different than in late successional wetlands.

Given all information to date, we believe that animal communities and the functions that control animal communities are on planned trajectory towards a recovered bottomland hardwood wetland. We suspect that overtime, as the plant community structure matures, variances in animal community structures between Pen Branch and control systems will lessen and tend toward a mature bottomland hardwood system.

Restoration goals are dependent on species or communities that are deemed valuable by management or the public. The restoration goal of Pen Branch is a mature bottomland hardwood community. If for example, the goal of restoration was to maximize fish densities, then restoration efforts can be tailored to keep the vegetation community at a level of disturbance that would optimize fish densities. The research findings give land and wildlife managers many more alternatives depending on the management objectives onsite.

Results of new and ongoing studies investigating nutrient and carbon processes will shed new light on the interactions that are occurring between biotic and abiotic components in the Pen Branch watershed. Once all the results of monitoring and research are integrated, we will have a better picture of what biotic and abiotic parameters have the most promise as wetland function indicators.

\section{Stream Communities}

\section{Stream Morphology and Stream Community Characteristics}

Investigators: Drs. Marcel Reichert and John Mark Dean, University of South Carolina.

In early fall 1995, thirteen sampling sites were selected in four stream systems (locations). The locations were Pen Branch ( 6 sites, 13 sections), Meyers Branch (1 site, 4 sections), Four Mile Run (3 sites, 12 sections) and Upper Three Runs ( 3 sites, 10 sections). Each site consisted of a consistent stream area, like the main channel of side stream. Each section consisted of a 30-50 meter stream stretch. The sections were marked and prepared for sampling the fish community. The fish community of each site was sampled using standard electrofishing techniques. Each section was sampled in 3 to 5 passes or runs. All runs were completed within a few hours on one day. Fish were identified to species level in the field. Some specimens were stored in $75 \%$ alcohol for later reference.

The stream characteristics were determined using two different protocols. At Meyers Branch, Four Mile and Pen Branch a variety of measurements in the streams were made to; (1) construct detailed maps of the sampling areas; (2) aid in calculating the Index of Biotic Integrity (IBI). At Upper Three Runs a more complex protocol was used. Measurements of streams and land distance between streams was measured along twelve transects perpendicular across the floodplain. The abiotic characterization consisted of measuring water properties (conductivity, temperature, $\mathrm{pH}$, and oxygen concentration), stream width and depth, current velocity. Furthermore, the percentage 
canopy cover, bottom type and the amount and nature of submerged structures was estimated. In each stream system the position of various locations was determined using GPS.

The sampling of the fish communities and the abiotic characterization of Meyers Branch, Four Mile and Pen Branch was completed by mid-January, 1996. All data were entered in the computer for data analyses. A preliminary report with the raw data and a description of the methodology was presented February, 1996. Due to flood conditions the abiotic characterization of the Pen Branch area could not be completed until May 1996.

\section{Current status}

Currently the data analyses for the calculation of the IBI is completed. In further analyses a comparison will be made with data collected in previous years and in other stream systems. Preliminary preparations to produce the maps have been made. A first version of the maps from Meyers Branch and Pen Branch is finished. The completion of a technical report is anticipated by March 1,1997. The report will contain a detailed methodology section, maps of the sampling areas, and the data and data analyses.

\section{References}

Paller, M., J. Dean, M. Reichert, C. Trettin and W. Specht. 1996. Use of biotic indices to measure the recovery of damaged streams (abstract). In: Nelson, E. (Ed.), Proceedings of the Restoration of Pen Branch Symposium, Savannah River Site. WSRC-MS-96-0257X, p 24.

\section{Ecological Risk Assessment and Stream Restoration Relative to Thermal Flow Disturbance}

Investigators: Dr. Dean Fletcher, David Wilkins and Dr. Gary Meffe, University of Georgia, Savannah River Ecology Lab.

The effects of past effluent release on present day fish communities are being addressed using Fourmile Creek and Pen Branch as replicate sites impacted by past thermal effluents and flow augmentation, and Upper Three Runs Creek and Meyer's Branch as replicate unimpacted control sites. Fishes in these streams are being studied at levels or organization ranging from individual (physiology and behavior), to population (demography and habitat segregation) to interspecific interactions in communities (structure and function). Such a comprehensive study will allow development of mechanistic models of cornmunity functional organization based on characteristics of individuals and individual species. Establishment of a long-term database will allow examination of past impacts and current restoration efforts on ecosystem stability and resilience. Collaboration with Carl Trettin/Randy Kolka and other members of the staff at the USDA Forest Service Center for Forested Wetlands Research and J. Vaun McArthur/Michelle Lakly at SREL is allowing an even more holistic documentation of ecosystem function in these systems.

\section{Risk Assessment}

Intensive sampling of stream fish communities and habitat structure began in these four streams in 1994 and has continued to the present. To date, seven seasonal samples have been taken, and an eighth is in progress. Sites were chosen to include major habitat types in the selected reaches of each stream. In January 1996, the number 
of sample sites distributed among these four streams increased from the original 48 to 55 as a result of a preliminary analyses. Surveys consist of multiple-pass electroshocking, identification and counting of collected individuals of all species, measurement of individuals of most species, and return of fish alive to the stream. To date, over 50,000 fish have been collected. Surveys are conducted in January (winter sample/pre-spawning for early spawners), and September (post spawning for summer spawning species). This timing maximizes the utility of our data for examining demographic patterns and seasonal patterns of habitat use.

Within each of the 55 sites, at least five permanent habitat transects have been established, upon which detailed information is collected, including channel dimensions, depth profiles, substrate types and firmness, presence and type of woody debris, aquatic vegetation, and canopy cover, water velocity, $\mathrm{pH}$, conductivity, and dissolved oxygen. Our depth profiles used with our elevation markers will allow documentation of stream bed erosion and sedimentation over time. Sediment loads in the water columns of each stream during flood events also may be analyzed in the future. The USDA Forest Service Center for Forested Wetlands Research is initiating vegetation surveys, hydrology, carbon cycling and light regimes in a subset of our sites in three streams. McArthur's lab at SREL has been examining aquatic invertebrates and additional water chemistry and primary production parameters in the two streams.

Preliminary analysis indicates that the impacted steams have a least as many species of fish as control streams, and two to five times the densities of individuals. Even though species richness seems similar, distribution of individuals among the species differs greatly. Impacted streams are heavily dominated by a few taxa of fishes, including some suckers, mosquitofishes, minnows, and sunfishes, a characteristic of disturbed areas. Unimpacted streams have a more even distribution of individuals among species, characteristic of more natural sites. Community compositions also differ, indicating a possible change in the functional organization of these communities. Past disturbances appear to be having long-term effects on the community structures in these streams.

Interspecific spawning interactions and demography of selected species are being examined in greater detail. We have learned that dusky shiners (Notropis cummingsae) migrate into slow, still waters to spawn on nests of redbreast sunfish (Lepomis auritus), and that the interaction is probably obligatory for the shiner. We also have discovered that, while in the host sunfish nests, the shiners feed on embryos and larvae, selectively eating host offspring. We have begun to extend these studies in four ways: a) we are documenting stream-wide patterns of nesting activities as a function of previous disturbance (disturbed streams vs. natural, undisturbed streams) and local habitat structure; b) we are comparing microhabitats of individual nests and their placement among mesohabitats within and among streams by beginning to characterize the local habitat structure (canopy development, aquatic vegetation, woody debris/cover, substrate type, water depth, temperature, distance to moving water, pool characteristics, and surrounding land use), size of nests, nest activity, distance from shore, and coloniality; c) we are using the number of nests observed in our study sites along with our community data to analyses demographic patterns of these species; and d) mating systems of redbreast sunfish are being examined using microsatellite DNA in collaboration with John Avise of the University of Georgia. All of these studies began in 1995 and are in progress.

Past studies have indicated differences in lipid cycling and reproduction patterns between dusky shiners in Fourmile Creek and Upper Three Runs. Monthly collections of dusky shiners were made in the Pen Branch (thermally impacted), Meyer's branch (unimpacted control stream) and the Salkahatchie River (modified canopy, but not thermally impacted). These collected dusky shiners are being used to study their growth, size, lipid storage, and reproductive patterns as a function of the systems in which they occur. Samples are being processed. 


\section{Restoration Activities}

The SRFS has divided the impacted Pen Branch stream corridor into a longitudinal series of cross-sections that mark unmanipulated control areas and experimental restoration sites. The experimental areas have been herbicided to kill existing vegetation, burned to remove ground cover, and replanted with native hardwood trees. Twenty-seven of our 55 study sites are distributed among these control and experimental sections of Pen Branch, and allow analysis of the effects of restoration efforts on the fish communities and the system. Data that had been collected prior to vegetation manipulation have established a baseline of fish communities before experimental restoration, and data from undisturbed streams are serving as a target endpoint of a successful restoration. Our current data collection is monitoring the shortterm effects of the restoration process as well as establishing an early trajectory of the recovery process. Again, our studies are being combined with the efforts of the above mentioned collaborators to produce a more holistic depiction of the system's recovery. Preliminary analysis indicates that removal of the low willow/shrub canopy has greatly increased aquatic macrophyte and fish abundance in the restoration areas. Long-term monitoring will be required to record the ultimate effectiveness of the restoration efforts.

\section{References}

Fletcher, D.E., S.D. Wilkins and G.K. Meffe. 1996. Ecological risk assessment and restoration relative to thermal and flow disturbance - fish ecology and stream habitat (abstract). In: Nelson, E. (Ed.), Proceedings of the Restoration of Pen Branch Symposium, Savannah River Site. WSRC-MS-96-0257X, p 15.

\section{Autotroph and Macroirvertebrate Post-Thermal Recovery and Restoration of a Coastal Plain Stream}

Investigators: Dr. J Vaun McArthur and Michelle Lakly, University of Georgia

The purpose of this study is to assess the recovery status of Pen Branch with regard to aquatic invertebrates. This will be accomplished by investigating the invertebrate community and stream characters that may influence insect distribution and production. This involves data collection from Pen Branch and two reference systems: Upper Pen Branch and Meyer's Branch. This study is designed in two distinct phases. Phase one which will conclude in December 1996 is a one year descriptive survey of the biota and ecological processes of Pen Branch and reference streams. This included the quantification and distribution of macroinvertebrates (artificial snag samplers, natural snags), algae (chlorophyll a and pheophytin), macrophytes (stream mapping), stream woody debris, and coarse and fine particulate organic matter. Additionally, changes in stream geomorphology since disturbance are being determined and compared to reference streams. These investigations will allow us to assess the current status Pen Branch and determine physical and biotic community changes since the cessation of thermal flows. This will be accomplished by comparison to a similar study on these systems conducted by Kondratieff and Kondratieff from 1983-1984 through Westinghouse. Additionally, we will be able to determine the short-term effects of the DOE/Forest Service restoration efforts on the macroinvertebrate communities and periphyton and macrophyte assemblages.

Phase II of the experiment was introduced to directly assess the effects of the DOE/Forest Service herbicide/replant restoration and determine its potential long-term application in the restoration and recovery of Coastal Plain streams. Specifically, Phase 
II will use the information gained in Phase I to conduct a manipulation experiment where woody debris, leaf litter, canopy closure and possibly stream morphology of Section F in Pen Branch will be altered to mimic the reference streams. The same investigations of the biota and ecological processes will be conducted in the manipulated section of Pen Branch and reference streams for an additional two year period. This manipulation will allow us the opportunity to determine the importance of physical factors such as woody debris, litterfall, macrophytes, river form and riparian zones in structuring aquatic communities in Pen Branch and influencing stream recovery in the Coastal Plain. Additionally, all sites in all sections of Pen Branch and Meyer's Branch were chosen to coordinate with an intensive fish ecology and stream habitat study conducted by Dr. Dean Fletcher and Dr. Gary Meffe at SREL. This is also true to hydrologic investigations which will be conducted by Dr. Carl Trettin and Dr. Randy Kolka from the Forest Service. Fortunately, we are in the unique position through our direct interaction and coordination with other experts such as these to evaluate the current recovery of a thermally impacted system, but most importantly to proactively suggest mechanisms that may be important to stream/riparian interactions, fish ecology, and invertebrate ecology in stream restoration.

\section{References}

Lakly, M.B. and J.V. McArthur. 1996. Autotroph and macroinvertebrate post-thermal recovery and restoration in Pen Branch: a descriptive and manipulation study (abstract). In: Nelson, E. (Ed.), Proceedings of the Restoration of Pen Branch Symposium, Savannah River Site. WSRC-MS-96-0257X, p 17.

\section{Vertebrate Communities}

\section{Reptile and Amphibian Characterization of the Pen Branch Corridor at the Beginning of Restoration.}

Investigators: Dr. Hugh Hanlin, University of South Carolina-Aiken, and Dr. David Guynn, Clemson University.

To determine the effectiveness of restoration efforts in the Pen Branch corridor, SRS, a study of recolonization by reptiles and amphibians was initiated in a collaborative effort by personnel from USC-Aiken and Clemson University funded through the South Carolina University Research and Education Foundation. The study was conducted from January 1, 1995, through September 30,1996, and its purpose was to gather baseline herpetofaunal population data for future use in the assessment of mitigation efforts in the Pen Branch corridor.

Drift fences with pitfall traps, coverboards, aquatic turtle traps, and modified minnow traps were used to sample reptiles and amphibians. A mark-recapture design was used to determine diversity and relative abundance of species and herpetofaunal utilization of all general forest and corridor habitat types. All individuals captured were identified (and, when possible, their sex determined), marked, and released at the capture site. Traps were set in eleven planting zones alternating between control strips and replanted strips for the purpose of allowing comparisons of diversity and relative abundance in planted and naturally revegetated strips. Drift fences were placed in buffer strips on upland sites immediately adjacent to the corridor for evaluating relationships between buffer strip width and reptile and amphibian population density and diversity. 
A total of 11,802 individual reptiles and amphibians representing 70 species were captured in 221,126 trap nights between January 1,1995, and June 30, 1996. Total captures equaled 13,834 of which $12 \%$ were recaptures and $3 \%$ escaped. The most frequently captured species was the eastern narrow-mouthed toad (Gastrophryne carolinensis; 3601 individuals captured) making up $30.5 \%$ of the total captures. The other top four species captured were: southern toad (Bufo terrestris; 19.1\%), southern leopard frog (Rana utricularia; 16.7\%), marbled salamander (Ambystoms opacum; $6.7 \%$ ), and slimy salamander (Plethodon glutinosus; 6.02\%). These five species represented about $79 \%$ of the total captures.

Of the 70 species captured, snakes were represented by 24 species $(524$ individuals), anurans by 16 species ( 8281 individuals), salamanders by 13 species (1818 individuals), turtles by 9 species (459 individuals), lizards by 8 species ( 718 individuals), and crocodilians by 1 species ( 2 individual American alligators).

Four presentations on this study have resulted in the publication of one paper and three abstracts. Detailed information on the herpetofauna of Pen Branch will be published in a Master's Thesis being prepared by Catherine Fulmer, Department of Forest Resources, Clemson University.

\section{References}

Fulmer, C.M., D.C. Guynn, Jr., J.R. Davis, H.G. Hanlin, and J.P. McLendon. 1996. Reptile and amphibian characterization of Pen Branch at the beginning of restoration (abstract). Proceedings of the Wildlife Society Annual Conference. 3: 84-85.

Fulmer, C.M., D.C. Guynn, Jr., J.R. Davis, H.G. Hanlin, and J.P. McLendon. 1996. Reptile and amphibian characterization of Pen Branch at the beginning of restoration (abstract). Proceedings of the Annual Conference of the Southeastern Fish and Wildlife A.gencies. 50: (In Press).

McLendon, J.P., H.G. Hanlin, C.M. Fulmer, and D.C. Guynn, Jr. 1996. Reptile and amphibian characterization of Pen Branch (abstract). In: Nelson, E. (Ed.), Proceedings of the Restoration of Pen Branch Symposium, Savannah River Site. WSRC-MS-96-0257X, p 19.

McLendon, J.P., H.G. Hanlin, and E. A. Nelson. 1996. Reptile and amphibian characterization of a thermally disturbed braided stream undergoing restoration near Aiken, SC. In: Webb, F.J., Jr. (Ed.), Proceedings of the Twenty-third Annual Conference on Ecosystems Restoration and Creation. (In Press).

\section{A Comparison of Avian Communities in Bottomland Hardwoods of Different Successional Stages}

Investigators: Drs. Karl Miller and David Chapman, University of Georgia.

Many Neotropical migrants have shown population declines over the last several decades. The reduction of breeding and wintering habitat are thought to be the main factors causing this decline. One type of habitat in the Southeast that is important to many avian species is bottomland hardwoods, particularly those in a later successional stage. As with most other habitat types, bottomlands have been decreasing in area. In an attempt to increase the amount of bottomlands, investigations have been made on how to increase the rate of succession, thereby providing preferred habitat for many avian 
species. However, it is unclear if such efforts return the bottomland forest to its original functional state.

\section{Objectives}

This study has two main focuses. First, the avian communities of bottomlands in different successional stages were compared. Second, the foraging behavior of three forest birds were described. The objectives were to ascertain the following:

Community Study

--Does the avian community differ between control sites and those that have been herbicided, burned, and received late successional hardwood planting?

--Are avian community parameters different between control sites and those that only receive hardwood planting?

--How do the avian communities differ between early, mid, and late successional bottomlands?

Foraging Study

--Is there a difference in how the three species forage?

--Do the birds prefer certain tree species on which to forage?

In addition to the above, this study will give future insight to the following:

--Can off site, later successional bottomland habitats, be used to predict future conditions in early successional bottomlands?

--What is the length of time necessary for avian communities to succeed to those normally associated with late successional bottomland hardwood forests?

--How do the treatments aid in the recovery of bottomland hardwoods?

\section{Study Design}

For the successional study, two creeks were required to represent mid and late successional bottomland hardwood forests that were similar in width to Pen Branch. Steel Creek was chosen for the mid-successional creek because it contained mature black willow and scattered bottomland hardwoods. Tinker Creek was chosen to represent a late successional bottomland hardwoods forest. This creek was relatively undisturbed for over 60 years and primarily contained mature bottomland hardwoods. For the foraging study, a variety of bottomland hardwoods were used. Appropriate sites had to contain mature bottomland hardwoods. Approximately ten sites were used, including Tinker Creek.

The fixed radius $(50 \mathrm{~m})$ point count census method was used to determine bird species diversity, richness, and abundance. A census was conducted from May 27th to June 22nd, 1994. In Pen Branch, one census point was located in each treatment and control block. Points were placed near the center of the drainage. Tinker and Steel Creek each had six census points. Each point was separated by approximately $200 \mathrm{~m}$ and was at least $50 \mathrm{~m}$ from the edge of the bottomland.

Each site was visited five times with three to five days between successive counts. All censuses were conducted between sunrise to 3.5 hours post sunrise. Census counts were five minutes in duration. Birds observed during this time were recorded into appropriate distance intervals from the center of the census plot. Birds observed within \pm 3 minutes of each census count were included for the species list of the site.

The continuous recording method was used to record the foraging behavior of the following species: White-eyed Vireo, Northern Parula, and Hooded Warbler. Observations were spoken into a tape recording then later transcribed with the use of a stopwatch. Upon locating a foraging bird, the following parameters were recorded: bird 
species, bird sex (if possible), tree species, foraging mode (glean, hover, hawk, hang, sally), substrate on which bird was foraging, height of tree, position of bird relative to the trunk and top of the tree, and time of day. Observations were primarily conducted from sunrise to 1300 hours.

\section{$\underline{\text { Results }}$}

On Pen Branch there were few differences in the avian community among treatments. However, plots that were herbicide treated, burned, and planted tended to have greater richness in 1994 and abundance in $1995(\mathrm{P}<0.05)$. Bird species composition differed slightly among treatments. Abundance of individuals was lower in the Steel Creek bottomland compared to Pen Branch and did not differ between Pen Branch and Tinker Creek. Species richness differed among all sites (lowest in Pen Branch, highest in Tinker Creek). Bird species diversity was greater in the Tinker Creek bottomland compared to Pen Branch. Short-distance migrants and species associated with forest edge/scrub habitats were more common in the early successional bottomland (Pen Branch) compared to the other sites. Neotropical migrants and interior species were most common in the late successional habitat (Tinker Creek).

There were slight differences in foraging behavior among the three bird species, but the sample size was relatively small. Foraging height was nearly similar between Hooded Warblers (102 foraging observations) and the White-eyed Vireos (64 foraging observations) $(x=6.4 \mathrm{~m})$ whereas Parula Warblers ( 82 foraging observations) foraged at mean height $9.0 \mathrm{~m}$. Hooded Warblers hovered almost as frequently as the other two species gleaned. Parula Warblers were common in both the inner and outer section of the tree whereas the White-eyed Vireo and Hooded Warbler spent more tome in the outer two-thirds of the branches. These results suggest niche differentiation through three main variables: foraging maneuver and position of the bird relative to the trunk and top of the tree.

\section{References}

The following are papers that have been published and submitted for publication or currently are being prepared for submission.

Buffington, J. M. 1996. A comparison of breeding bird communities in bottomland hardwood forests of different successional stages. M. S. Thesis, Univ. Of Georgia, Athens, 68pp.

Buffington, J. M., J. C. Kilgo, R. A. Sargent, K. V. Miller, and B. R. Chapman. A comparison of bird communities in bottomland hardwood forests of different successional stages. The Wilson Bull. (Accepted).

Buffington, J. M., J. C. Kilgo, R. A. Sargent, K. V. Miller, and B. R. Chapman. Effects of restoration techniques on the breeding bird communities in a thermally impacted bottomland hardwood forest. Wildl. Soc. Bull. (Submitted).

Buffington, J. M., K. V. Miller, and B. R. Chapman. 1996. Effects of revegetation techniques on the avian communities in a thermally impacted bottomland hardwood forest (abstract). In: Nelson, E. (Ed.), Proceedings of the Restoration of Pen Branch Symposium, Savannah River Site. WSRC-MS-96-0257X, p 13.

Buffington, J. M., J. C. Kilgo, R. A. Sargent, K. V. Miller, and B. R. Chapman. A comparison of breeding bird communities in bottomland hardwood forests of different successional stages. Presented @ 113th Mtg, Amer. Ornithol. Union, Cincinnati, $\mathrm{OH}$. 
WSRC-TR-97-00273

\section{Pen Branch Small Mammel Program}

Investigators: Dr. Lynn Wike, Erica Stieve, Tracy Parker and John Gass, Savannah River Technology Center

A small mammal sampling program was conducted in the Pen Branch restoration area durning the summer of 1996 . Six transects across the corridor corresponding to herpetofaunal study lines were selected to represent upper, middle and lower corridor segments. Each segment had one line from a control area and one from an experimental area. Four Sherman live traps were placed at each of the herpetofaunal sampling coverboard stations along each transect. Traps were baited with a mixture of birdseed, rolled oats, and peanut butter. Traps were set June 10th and checked daily until June 28 th. Trapped animals were identified, sexed, weighed, and ear tagged. One hundred and ninety two traps operating for 18 nights provided 3,456 trap-nights of effort. Four hundred and eight captures occurred for a sucess rate of $11.8 \%$. Species captured included Cotton rats (Sigmodon hispidus, 151), Rice rats (Oryzomys palustris, 117), Cotton mice (Peromyscus gossypinus, 107), Southeastern short-tailed shrew (Blarina carolinensis, 8), and single captures of Golden mouse (Ochrotomys nuttalli), Wood rat (Neotoma floridana), and Star-nosed mole (Condylura cristata). Data are currently being analyzed for differences in diversity and abundance between various segments of the corridor as well as population estimates for the entire corridor.

\section{References}

Stieve, E., T. Parker, and J. Gass. 1996. A small mammal survey of Pen Branch, Lost Lake, and an isolated wood lot. Presentation at ORISE intern display, July 25, 1996. WSRC-MS-96-0491.

\section{Vegetation}

\section{Comparison of Biomass Partitioning and use of Physiological Parameters in Determining Long Term Survival of Four Wetland Tree Species}

Investigators: Dr. Donal Hook and Amy Rozelle, Clemson University.

\section{Introduction}

The purpose of this project was to assess physiological and morphological responses of four species under delta flooding regimes and to evaluate their potential to survive in areas akin to this. In February of 1994, bald cypress (Taxodium distichum), water tupelo (Nyssa aquatica), swamp tupelo (Nyssa sylvatica) and green ash (Fraxinus pennsylvanica) seedlings were planted in the Pen Branch delta of the Savannah River floodplain in an area impacted by thermal effluent and extended hydroperiods. These species were chosen because of their high flood tolerance and similarity to the species composition of the original forest. The soil in Pen Branch was saturated for the majority of the two year study period. In general, the headwaters of Pen Branch have been described as an undisturbed blackwater stream but the floodplain has been heavily impacted by effluents from nuclear reactor cooling systems. A change in the geomorphology of the area is evidenced by creation of a fan shaped delta with a narrow 
tail. This change resulted in less drainage from the delta and increased inundation and siltation.

\section{Methods}

Eight $40 \mathrm{~m}^{2}$ plots were laid out. A total of four sites were designated with two plots in each site: they were cleared, grass, willow, and muck. One area was cleared with a weedeater prior to planting while another area was comprised of dense grass cover and left undisturbed. Another area was dominated by black willow (Salix nigra). The muck site was characterized by higher water tables and less grass than the other three sites. Seedlings were planted at a $2 X 2$ foot spacing. Each plot consisted of four rows of 50 seedlings, one row for each species.

A total of twelve sampling runs were made over the coarse of two years--1994: May, July, August, October, November, December, and 1995: March, April, May, July, August, and September. For each sampling period, six seedlings of each species were lifted from the plots in a random fashion. Root tips were rinsed, excised, and stored immediately in liquid nitrogen to cease all enzymatic activity. The remainder of each seedling was stored in a refrigerated cooler until the time they were returned to the lab for further processing.

In the lab, cross sections of the main and lateral root system were cut at two inch intervals, placed in a tetrazolium dye solution with sodium phosphate buffer, and placed in the dark. After twenty hours root viability was assessed by presence of a pink color. Tissue that stained pink was assumed to be alive.

Alcohol dehydrogenase $(\mathrm{ADH})$ was extracted from root tips within 72 hours. Root tips were removed from liquid nitrogen, weighed, homogenized in extraction buffer, and centrifuged at $4{ }^{\circ} \mathrm{C}$ for 20 minutes. The samples were then assayed at $340 \mathrm{~nm}$ on a spectrophotometer to determining activity.

Seedlings were separated into leaves, stems, and roots, and fresh and dry weights were measured as well as height and diameter. Prior to drying, leaf area was determined using Agimage software in combination with a light box/camera setup.

\section{Results}

$\mathrm{ADH}$ activity of bald cypress roots averaged about 0.035 units per mg dry weight whereas the other three species averaged less than 0.01 units per mg dry weight. All four species showed a strong seasonal response for ADH activity with the rate being highest in the spring and rapidly decreasing to near zero during late summer. Bald cypress, water tupelo, and swamp tupelo showed recovery of $\mathrm{ADH}$ activity in the fall or maintained a low level of activity whereas green ash $\mathrm{ADH}$ activity fell to zero in August and did not recover. Determining amount of $\mathrm{ADH}$ activity in root tips is one way of quantifying the seedling's capacity for anaerobic respiration. Anaerobic respiration is an important adaptive strategy used by flood tolerant species for metabolizing carbohydrates initially following flooding.

The root viability test is another indicator of response to this type of environment. The tetrazolium dye test provided estimates of the percentage of the root system that was viable over time. Staining by tetrazolium dyes suggested that a smaller percentage of green ash roots were alive than the other three species in the late fall. If these relationships hold up through next spring, they may prove to be useful tools for early assessment of potential survival of planted seedlings in wetlands. Biomass allocation data provided insight into how each species responded to this environment for two growing seasons.

All of these parameters are being combined into a model to demonstrate how they act in concert and to show relative responses of each species over time to prolong soil saturation and inundation. The combined results suggest that Fraxinus pennsylvanica is 
showing signs of stress while the other three species appear to be adapting well to this environment. This information should be quite useful in projecting reforestation results in Pen Branch and in similar areas.

\section{References}

Rozelle, A.L., and D.D. Hook. 1996. Comparison of biomass partitioning and use of physiological parameters in determining long term survival of four wetland tree species (abstract). In: Nelson, E. (Ed.), Proceedings of the Restoration of Pen Branch Symposium, Savannah River Site. WSRC-MS-96-0257X, p 22.

Rozelle, A.L., D.D. Hook, and M.R. McKevlin. 1995. Use of physiological parameters of seedling roots for predicting survival of four wetland tree species (abstract). Presented at 16th Annual Meeting, Society of Wetland Sciences, Boston, Mass.

\section{The Use of Root Pruning and Tree Shelters in Regenerating Forested Wetlands in Pen Branch}

Investigator: Dr. William Conner, Clemson University.

In the Pen Branch delta the feasibility of planting wetland species was examined (funding from Center for Forested Wetlands Research, USFS, Charleston, SC). Species chosen for planting were bald cypress (Taxodium distichum), water tupelo (Nyssa aquatica), (swamp tupelo) Nyssa sylvatica, and green ash (Fraxinus pennsylvanica). Objectives included: monitoring above- and below-ground biomass changes in planted seedlings, determining growth and survival rates, and using these data to develop planting guidelines for future restoration efforts. On four sites seedling roots were pruned to compare responses to non-pruned roots. Additionally, tree shelters were placed on a portion of the seedlings to evaluate effects on seedling response. Light quality and quantity differences were measured. Differences between root pruned and non-root pruned seedlings were variable depending on the species and area in which they were planted. Moderate pruning of roots was not detrimental to seedling growth and establishment. Tree shelters improved seedling height growth and survival. The amount of herbaceous competition in an area was directly related to the quantity of light an area receives.

One-year-old planting stock can be root pruned, thus making it easier to plant under flooded conditions with the best results obtained with Taxodium distichum and Nyssa aquatica. Root pruning does not seem to significantly affect growth of these species, and in some cases may stimulate root growth which could be beneficial in the long run. With enough sunlight, root pruned seedlings could be used to revegetate disturbed swamp areas where natural regeneration has not occurred. The impacts of root pruning on long-term survival and growth are unknown and require further study. Tree shelters significantly improved survival and height growth of all four species. Measurement of tree shelter seedlings was conducted in 1994, 1995, and 1996.

\section{References}

Funderburk, E.L. 1995. Growth and survival of four forested wetland species planted on Pen Branch Delta, Savannah River Site, S. C., MS Thesis, Clemson Univ.

Funderburk, E.L. and W.H. Conner. 1996. Survival and growth of planted forested wetland species, Pen Branch Delta, Savannah River Site, S.C. Southern Forested 
Wetlands workshop, Clemson, SC, 25-27 March.

Conner, W.H., L.W. Inabinette, and E.L. Funderburk. 1996. The use of root pruning and tree shelters in regenerating forested wetlands in Pen Branch. In: Nelson, E. (Ed.), Proceedings of the Restoration of Pen Branch Symposium, Savannah River Site. WSRC-MS-96-0257X, p 20.

Funderburk, E.L. and W.H. Conner. 1995. Growth and survival of forested wetland species planted in Pen Branch Delta on Savannah River Site, SC. Association of Southeastern Biologists, Knoxville, TN, 19-21 April.

Funderburk, E.L. and W.H. Conner. 1995. Restoration techniques for a thermally altered forested wetland. South Carolina Academy of Science, Greenville, SC, 7-8 April.

\section{Optimum Overstory Condition for the Survival and Growth of Late-Successional Seedlings}

Investigators: Dr. Martha McKevlin and Neil Dulohery, USDA Forest Service, Center for Forested Wetlands Research, Charleston, SC.

\section{Introduction}

Salix nigra (black willow) and Alnus serrulata (alder) are both common earlysucessional pioneer species in many riparian systems of the Southeast, colonizing newly exposed hydric sites influenced by disturbance. The extensive willow and alder thickets along the Pen Branch corridor of the Savannah River Site (SRS) make operational scale planting of seedlings difficult, and survival and growth of planted seedlings questionable due to competition both for light and below ground resources. This study was established to better understand the effects of overstory removal on environmental factors influencing survival and growth of planted seedlings. Specific objectives were to 1) determine the optimum overstory condition for planted seedlings based on seedling survival and growth, 2) determine the effect of overstory condition on specific microsite factors such as light quality and quantity, soil temperature, depth to water table, and herbaceous competition, and to 3) determine the influence of these environmental characteristics on seedling survival, growth, and biomass allocation patterns.

\section{Methods}

Four tree species,Taxodium distichum (bald cypress), Nyssa aquatica (water tupelo), Quercus michauxii (swamp chestnut oak), and Fraxinus pennsylvanica (green ash) were planted under four levels of competition control for a $4 \mathrm{X} 4$ factorial arrangement of treatments. Species were selected to represent a range of flood and shade tolerances among wetland species. Competition-control treatments were applied to whole plots, with species in subplots. Each subplot measured $12 X 57 \mathrm{ft}$. and contained five rows of 20 seedlings planted on a $3 X 3 \mathrm{ft}$. spacing. A treated buffer of $30 \mathrm{ft}$. was established around each plot to ensure uniform light and competition within plots. The competition-control treatments were as follows: 1) none; 2) intermediate control, stems left in place; 3) complete control, stems left in place; and 4) complete control, clearcut.

Height growth, survival and possible sources of mortality were monitored in the spring of 1994, winter of 1994-1995 and winter of 1995-1996. Herbaceous competition was measured by harvesting all above ground herbaceous plants in $0.5 \mathrm{~m}^{2}$ plots in August of 1994 and 1995. Light quality and transmittance were monitored on minimal clouding days during the summers of 1994 and 1995 . Soil temperatures at $5 \mathrm{~cm}$ was recorded 
during several weeks during the summer of 1994 . Water table depth was monitored on 1 to 3 hour intervals for the duration of the project.

\section{Results}

Initial results indicate that the four overstory competition control treatments resulted in significant differences in 1) diurnal fluctuations in depth to the water table, 2) light environment of the seedlings both in terms of quantity and quality, and 3) biomass of herbaceous competition. Larger diurnal fluctuations in the water table are found in treatments where the willow canopy was undisturbed. As expected, light transmittance is directly related to the level of canopy manipulation in the treatments. Greater light transmittance in the clearcut plots has led to greater herbaceous competition in these plots. Analysis of seedling height growth and survival data is currently being conducted. Initial results suggest differences in both height growth and survivalship among species and among treatments. It appears that a sparse to moderate willow canopy can ameliorate the stresses of growth limiting hydrology and herbaceous competition and be beneficial to the establishment, growth and survival of tolerant bottomland hardwood species.

\section{References}

McKevlin, M.R. and N. Dulohery. 1996. Optimum overstory condition for survival and growth of late-sucessional seedlings. In: Nelson, E. (Ed.), Proceedings of the Restoration of Pen Branch Symposium, Savannah River Site. WSRC-MS-960257X, p 11.

Dulohery, N.J., C.S. Bunton, C.C. Trettin and W.H. McKee. 1995. Reforestation, Monitoring, and Research at Pen Branch: Restoring a Thermally-Impacted Wetland Forest. Establishment Report. USDA Forest Service. 55 pps.

\section{Soil Nutrients and Carbon Flows}

\section{Soil Organic Matter Development and Characterization: Successional Patterns on a Forested Floodplain}

Investigators: Dr. Graeme Lockaby and John Wigginton, Auburn University.

Soil organic matter (SOM) is a critical interface for the exchange of nutrients between vegetation and soil, and is directly linked to patterns of forest productivity. Although there has been some research regarding SOM in upland forests, there is less understanding of SOM formation patterns in riverine systems. Therefore, we are studying forest floor development and SOM formation in four seral stages of floodplain forests on the Savannah River in South Carolina. Three hypotheses are being addressed: 1) rates of conversion of litter to SOM will be greatest during early seral states and reach an equilibrium during mid-succession; 2) the enriched labile fraction will increase in importance as succession proceeds; and 3 ) forest floor mass and $\mathrm{C}$ will be maximized during mid-succession and $\mathrm{C}: \mathrm{N}$ ratios will decline as seral stages progress thereafter. ANOVA and non-linear regression analyses will be performed to compare the relationships among stages of succession within the floodplain forest.

Soil and forest floor sampling was completed in April and June 1996. Except for phosphorus determinations, analyses of the forest floor material are complete, while 
physical fractionation and ensuing laboratory analyses of the soil samples are now beginning. Forest floor organic matter mass was found to increase rapidly during early succession, reaching a maximum of $657 \mathrm{~g} / \mathrm{m}^{2}$ at Pen Branch A (early-mid succession) and decreasing to $338 \mathrm{~g} / \mathrm{m}^{2}$ at the late succession sere of Meyer's Branch. Studies of upland forest in Mississippi have also found the pattern of a rapidly developing forest floor with maximum levels attained during mid-succession and declining thereafter, although overall estimates for forest floor dry weight in the present study are about one third less.

Marked differences in the composition of the forest floor fractions from the various stages were discovered. The herbaceous fraction steadily declined through succession from $74 \%$ in the earliest stage to less than $1 \%$ in the latest stage of succession. Conversely, the amount of woody foliage increased from $6.7 \%$ in the earliest stages of succession to over $70 \%$ in late succession. Carbon and nitrogen estimates reflect patterns of increasing concentration during early succession, reaching an equilibrium during the later stages of succession. Average carbon concentration for all four sites was about $42 \%$ while nitrogen was $1.16 \%$. Carbon and nitrogen ratios were relatively constant throughout all stages of succession, ranging from 41 to 48 .

Measures of the rate of transformation of litter to soil organic matter using the lignocellulose index were not significantly different between stages of succession. Higher ratios of lignin to lignin+cellulose are predicted in later stages of succession due to the expected increase in a refractory lignin component over time. The hydrologic dynamics of floodplains, in conjunction with the warm climates of the southeastern U.S., may prevent the application of this procedure to studies of succession in floodplain forests. Percent lignin increases from $13 \%$ to $16 \%$ in early/mid succession and reaches an equilibrium of about $14 \%$ in later stages. Lignin and nitrogen ratios were also not significantly different with values ranging between 12 and 14.

\section{References}

Wigginton, J.D., B.G. Lockaby, and C.C. Trettin. 1996. Soil organic matter formation during succession on a forested floodplain. Poster Presentation, Ecological Society of America 81st Annual Meeting, Providence, Rhode Island.

\section{Comparison of Carbon and Nutrient Fluxes among Wetland Systems at Different Successional Stages.}

Investigators: Drs. Randall Kolka and Carl Trettin, USDA Forest Service, Center for Forested Wetlands Research.

Our study is investigating carbon and nutrient fluxes among three wetland systems at various stages of succession. To perform this study, we are combining hydrologic monitoring and water chemistry analysis to determine if transport process vary among the Pen Branch, Fourmile Creek, and Meyers Branch wetlands. Differences in carbon and nutrient allocation and transport processes among and within systems will be used as one set indicators to establish a framework for wetland restoration effectiveness. This study was developed in close association with another cooperative study that will investigate insitu pools of carbon and nutrients and the influence of decomposition on the release of carbon and nutrients from these pools. 


\section{Methods}

Monitoring is being performed in one control and one planted strip in the upper corridor of Pen Branch with identical monitoring in Fourmile (FM) and Meyers Branch (MB) corridors. Monitoring is being conducted at two levels of intensity. Intensive riparian monitoring is designed to effectively address both our research needs and to enhance the knowledge base of ongoing research addressing fish and macroinvertebrate habitat. Less intensive monitoring will be conducted throughout the wetlands and uplands in the three systems to characterize watershed level processes that are important to wetland functions.

\section{Hydrology and Water Chernistry}

Hydrologic transects are currently being established perpendicular to the stream channel from the riparian vegetation plots described above. Hydrologic transects run into the upland a short distance to determine the influence of those inputs into the corridor. Each hydrologic plot consists of a nested set of piezometers $(50,100,150$ and $200 \mathrm{~cm}$ ), a continuously recording or manually recording well which will also be used to sample for soil water chemistry (composite sample from 0-175 cm). Stream stage height will be measured either manually or with a recording well. Streamflow will be estimated with knowledge of stream morphometry and stage height relationships.

A transect of three throughfall collectors (analyzed for both volume and water chemistry) will be placed in one of the riparian vegetation plots within each vegetation zone and coordinated with the litterfall collectors (see following study). Open precipitation volume and chemistry will be monitored in an opening centrally located among watersheds. Throughfall, open precipitation, soil water and stream grab samples will be analyzed. Waters will be analyzed for a variety of water quality parameters with particular attention paid to total organic carbon, dissolved organic carbon, nitrogen, phosphorus, total dissolved solids, $\mathrm{pH}$ and dissolved oxygen.

\section{Expected Results}

1) With knowledge of organic carbon and nutrient pools (soils and vegetation) and turnover (decomposition and deposition) from the following study and volumetric fluxes between pools (hydrology and water chemistry) from this study, we expect to characterize the mass balance for these parameters and assess the influence organic carbon has on the transport of forest nutrients among the three systems.

2) Develop sensitive indicators of wetland conditions by comparing the results of monitoring among the three systems. We expect to establish indicator relationships among and within watersheds based on the stage of wetland recovery and forest succession.

3) We expect our information to support others' findings to define cause and effect relationships linking the terrestrial system with the stream habitat and biota.

\section{Distribution and Function of Organic Matter Pools among Systems of Different Successional Stages}

Investigators: Dr. Michael Aust and Laura Giese, Virginia Polytechnic University.

A new study investigating carbon and nutrient pools among bottomland hardwood wetlands is being initiated in 1997. This study is associated with the previous study on carbon and nutrient fluxes. The focus of this study will be to characterize the 
carbon and nutrient pools in three bottomland hardwood systems that are considered to be a continuum of succession. The two studies will be integrated to develop a holistic approach to the dynamic processes that affect carbon and nutrient allocation and transport in bottomland hardwood wetlands.

\section{$\underline{\text { Methods }}$}

Monitoring of soils, vegetation, litterfall and decomposition will be performed in one control and one planted strip in the upper corridor of Pen Branch with identical monitoring in Fourmile (FM) and Meyers Branch (MB) corridors. As with the previous study, intensive monitoring will be conducted in the riparian zone with less intense monitoring occurring throughout the wetland.

\section{Vegetation}

Three long-term riparian vegetation plots are established in each of the above locations and associated with Dr. Dean Fletcher's fish community plots. Within each riparian vegetation plot, a nested approach will be used to evaluate species richness, diversity and biomass. One riparian vegetation plot within each location is being monitored for litterfall inputs with a transect of three litterfall collectors. These same plots will be involved in a litterfall decomposition study starting in 1997. Also, three long-term vegetation plots that are not associated with the stream are randomly located within each of the vegetation zones discussed above with additional plots located in planted and control strips in the lower Pen Branch corridor, and in the Pen Branch delta. Vegetation evaluation will follow the same protocol as above for the riparian sites. We are currently developing methods to characterize instream carbon and nutrient pools and relevant studies addressing instream processes.

Soils

Within each vegetation plot and along the hydrologic transects, soils will be described and sampled. Soils will be sampled for bulk density and saturated hydraulic conductivity in the field. Soil samples will be collected by depth for analysis of $\mathrm{pH}$, particle size, C, N, P, exchangeable cations and anions. We are currently developing methods to investigate soil redox status.

\section{Expected Results}

Our results will be an integral part of the overall assessment of carbon and nutrient relationships among bottomland hardwood wetlands at various stages of succession. We expect to find differences in the mass of carbon and nutrients when comparing similar pools among locations. We also expect to find the allocation of carbon and nutrients among these pools to be different across the sucessional gradient. Measurements of decomposition rates and soil redox status will allow us to take a process oriented approach to describe these differences. Like the previous study, we expect our information to support others' findings linking the terrestrial system with the stream system. Finally, we expect that some of the parameters measured will become indicators of wetland recovery and add to the overall assessment of the future of Pen Branch. 
WSRC-TR-97-00273

\section{Wetland Assessment}

\section{Development of a Wetland Evaluation Technique Specific to the Reforested Pen Branch Corridor and Delta}

Investigators: Dr. Carl Trettin, Center for Forested Wetland Research, Dr. Eric Nelson, Savannah River Technology Center, Brad Shaver and Brian Helmlinger, College of Charleston.

\section{Introduction}

The need to evaluate wetland functions and values is derived from the need to manage, conserve and restore wetland ecosystems. Restored sites must be evaluated and compared to references of "healthy and functional" wetlands to determine the success of the rehabilitation process. The subject of this study is Pen Branch Creek, a site deforested by thirty years of thermal effluents from $\mathrm{K}$ reactor on the Savannah River Site. Discharge ended in 1989 when K reactor was shut down. In 1991, the DOE initiated actions to mitigate impacts of the thermal discharge by replanting the native bottomland hardwoods. The project is based on two underlying objectives. First, we develop an assessment methodology specific to Pen Branch Corridor and Delta on the Savannah River Site in Aiken, S.C. Second, in order to assist in future research, we complete an annotated bibliography referencing all relevant information about Pen Branch and the components of its rehabilitation.

\section{Approach}

We began with an evaluation of existing wetland assessment methodologies, evaluating both the strengths and weaknesses of each. Using these assessment tools and the wetlands literature in conjunction with the objectives outlined in the Establishment Report for the reforestation project, we developed a set of measurements critical to the evaluation project. Rather than choosing one evaluation technique which best meets the needs of the entire project, we integrated various portions of the evaluation techniques specific for each phase of the process. We also addressed the need for a reference wetland, or undisturbed site, with which we can compare the progress of the restored system.

To obtain this data we reviewed literature written about Pen Branch and interviewed the science staff working on the Savannah River Site (SRS). We collected data on potential reference sites, attempting, where possible, to cite research collected at similar times, representative locations, and using similar protocols for both sites. At this point we identified data gaps and potential areas for future research. The bibliography of relevant readings, which includes approximately 120 references, should provide direction for this research and prevent duplication of data sets collected during previous studies.

Comparisons between Pen Branch and the reference wetland were made using data obtained to describe each function. In some instances, this is no more complex than comparing the values of two measurements, and in other cases, where appropriate methods exist, indexes of function performance are constructed. Once comparisons have been made, we will focus on the key queries of the evaluation: At what level are the essential functions of a wetland being performed by Pen Branch? and to what degree is Pen Branch agrading toward a bottomland hardwood system? The answer to the second of these questions is supplemented with possible areas of improvement to the reforestation project. 


\section{Expected Results}

We collected data on the following categories: aquatic macroinvertebrate and fish communities, water quality, vegetative community, stream morphology, hydrology, nutrient mineralization, and decomposition. To date, analyses has been limited to aquatic macroinvertebrate and fish community, water quality, and vegetative community.

These indicators of macroinvertebrate community health are mean number of taxa per sampler, mean organism density, mean biomass, and total number of taxa collected. Aquatic macroinvertebrate data for the reforested wetland site show higher measures in all four of the indicators used to characterize this community as compared to the undisturbed reference wetland. Using chronological data starting from the period of thermal impact to post reforestation we have observed an increase in the measures of all four indicators.

Fish community data in the reforested wetland site indicate fish populations to be more diverse, more dense, and more rich in sensitive species, compared to the undisturbed reference site. In the process of characterizing the fish populations, we were involved in the calculation of indices of biotic integrity based on fish population data. To date, these indices indicate higher levels of biotic integrity and freedom from ecosystem disturbance in the reforested wetland site compared to the pristine reference site.

To characterize water quality at both the reforested and undisturbed sites we compared measures of $\mathrm{pH}$, dissolved oxygen, conductivity, hardness, velocity and temperature. In addition to obvious changes in water temperature and velocity, we have noted a stepwise increase in conductivity following the cessation of thermal effluent in Pen Branch. The $\mathrm{pH}$, dissolved oxygen, and hardness have remained relatively unchanged and comparable between the two sites.

The most distinct differences we have noted between the two sites have been in the vegetative communities. Although the diversity and net primary production in the disturbed site has surpassed that of the pristine site, the "desirable species" struggle to establish themselves as the dominant vegetative class in the reforested site.

The results of this project will be useful in three ways. The site specific wetland evaluation method will be used to determine the progress of the reforestation project in Pen Branch and as a conceptual model for the evaluation of similar restored sites. The bibliography will be used to reference existing evaluation techniques, to provide guidance for future investigations of wetland functions and their indicators, and to establish a working data set (water quality, vegetative community, aquatic community) for Pen Branch and other similar bottomland hardwood sites.

\section{Compilation of Literature}

One reference that deserves special mention is:

Nelson, E. A. 1996. The Restoration of Pen Branch: defining and measuring the progress of a thermally impacted stream becoming a functional wetland ecosystem. Abstracts from Symposium held on Feb. 13, 1996, Savannah River Site. WSRC-MS-96-0257X.

To facilitate the integrated focus of research occurring on the Pen Branch system, a symposium was organized by the Savannah River Technology Center. The workshop provided the first opportunity for researchers from diverse fields to discuss results and interpretations of their own studies in the context of others research. 
Buffington, J. M. 1996. A comparison of breeding bird communities in bottomland hardwood forests of different successional stages. M. S. Thesis, Univ. Of Georgia, Athens, 68pp.

Buffington, J. M., J. C. Kilgo, R. A. Sargent, K. V. Miller, and B. R. Chapman. A comparison of bird communities in bottomland hardwood forests of different successional stages. The Wilson Bull. (Accepted).

Buffington, J. M., J. C. Kilgo, R. A. Sargent, K. V. Miller, and B. R. Chapman. Effects of restoration techniques on the breeding bird communities in a thermally impacted bottomlanid hardwood forest. Wildl. Soc. Bull. (Submitted).

Buffington, J. M., K. V. Miller, and B. R. Chapman. 1996. Effects of revegetation techniques on the avian communities in a thermally impacted bottomland hardwood forest (abstract). In: Nelson, E. (Ed.), Proceedings of the Restoration of Pen Branch Symposium, Savannah River Site. WSRC-MS-96-0257X, p 13.

Buffington, J. M., J. C. Kilgo, R. A. Sargent, K. V. Miller, and B. R. Chapman. A comparison of breeding bird communities in bottomland hardwood forests of different successional stages. Presented @ 113th Mtg, Amer. Ornithol. Union, Cincinnati, $\mathrm{OH}$.

Conner, W.H., L.W. Inabinette, and E.L. Funderburk. 1996. The use of root pruning and tree shelters in regenerating forested wetlands in Pen Branch. In: Nelson, E. (Ed.), Proceedings of the Fiestoration of Pen Branch Symposium, Savannah River Site. WSRC-MS-96-0257X, p 20.

Dulohery, N.J., C.S. Bunton, C.C. Trettin and W.H. McKee. 1995. Reforestation, Monitoring, and Research at Pen Branch: Restoring a Thermally-Impacted Wetland Forest. Establishment Report. USDA Forest Service. 55 pps.

Fletcher, D.E., S.D. Wilkins and G.K. Meffe. 1996. Ecological risk assessment and restoration relative to thermal and flow disturbance - fish ecology and stream habitat (abstract). In: Nelson, E. (Ed.), Proceedings of the Restoration of Pen Branch Symposium, Savannah River Site. WSRC-MS-96-0257X, p 15.

Fulmer, C.M., D.C. Guynn, Jr., J.R. Davis, H.G. Hanlin, and J.P. McLendon. 1996. Reptile and amphibian characterization of Pen Branch at the beginning of restoration (abstract). Proceedings of the Wildlife Society Annual Conference. 3: 84-85.

Fulmer, C.M., D.C. Guynn, Jr., J.R. Davis, H.G. Hanlin, and J.P. McLendon. 1996. Reptile and amphibian characterization of Pen Branch at the beginning of restoration (abstract). Proceedings of the Annual Conference of the Southeastern Fish and Wildlife Agencies. 50: (In Press).

Funderburk, E.L. 1995. Growth and survival of four forested wetland species planted on Pen Branch Delta, Savannah River Site, S. C., MS Thesis, Clemson Univ.

Funderburk, E.L. and W.H. Conner. 1996. Survival and growth of planted forested wetland species, Pen Branch Delta, Savannah River Site, S.C. Southern Forested Wetlands workshop, Clemson, SC, 25-27 March.

Funderburk, E.L. and W.H. Conner. 1995. Growth and survival of forested wetland 
species planted in Pen Branch Delta on Savannah River Site, SC. Association of Southeastern Biologists, Knoxville, TN, 19-21 April.

Funderburk, E.L. and W.H. Conner. 1995. Restoration techniques for a thermally altered forested wetland. South Carolina Academy of Science, Greenville, SC, 7-8 April.

Gartner, D. 1996. Results of 1996 Pen Branch Vegetation Monitoring Survey. USDA Forest Service Report. 9 pps.

Lakly, M.B. and J.V. McArthur. 1996. Autotroph and macroinvertebrate post-thermal recovery and restoration in Pen Branch: a descriptive and manipulation study (abstract). In: Nelson, E. (Ed.), Proceedings of the Restoration of Pen Branch Symposium, Savannah River Site. WSRC-MS-96-0257X, p 17.

McKevlin, M.R. and N. Dulohery. 1996. Optimum overstory condition for survival and growth of late-sucessional seedlings. In: Nelson, E. (Ed.), Proceedings of the Restoration of Pen Branch Symposium, Savannah River Site. WSRC-MS-96$0257 \mathrm{X}, \mathrm{p} 11$.

McLendon, J.P., H.G. Hanlin, C.M. Fulmer, and D.C. Guynn, Jr. 1996. Reptile and amphibian characterization of Pen Branch (abstract). In: Nelson, E. (Ed.), Proceedings of the Restoration of Pen Branch Symposium, Savannah River Site. WSRC-MS-96-0257X. p 19.

McLendon, J.P., H.G. Hanlin, and E. A. Nelson. 1996. Reptile and amphibian characterization of a thermally disturbed braided stream undergoing restoration near Aiken, SC. In: Webb, F.J., Jr. (Ed.), Proceedings of the Twenty-third Annual Conference on Ecosystems Restoration and Creation. (In Press).

Paller, M., J. Dean, M. Reichert, C. Trettin and W. Specht. 1996. Use of biotic indices to measure the recovery of damaged streams (abstract). In: Nelson, E. (Ed.), Proceedings of the Restoration of Pen Branch Symposium, Savannah River Site. WSRC-MS-96-0257X, p 24.

Rozelle, A.L., and D.D. Hook. 1996. Comparison of biomass partitioning and use of physiological parameters in determining long term survival of four wetland tree species (abstract). In: Nelson, E. (Ed.), Proceedings of the Restoration of Pen Branch Symposium, Savannah River Site. WSRC-MS-96-0257X, p 22.

Rozelle, A.L., D.D. Hook, and M.R. McKevlin. 1995. Use of physiological parameters of seedling roots for predicting survival of four wetland tree species (abstract). Presented at 16th Annual Meeting, Society of Wetland Sciences, Boston, Mass.

Stieve, E., T. Parker, and J. Gass. 1996. A small mammal survey of Pen Branch, Lost Lake, and an isolated wood lot. Presentation at ORISE intern display, July 25, 1996. WSRC-MS-96-0491.

Wigginton, J.D., B.G. Lockaby, and C.C. Trettin. 1996. Soil organic matter formation during succession on a forested floodplain. Poster Presentation, Ecological Society of America 81st Annual Meeting, Providence, Rhode Island. 